\title{
A Study on the Plant Litter Decomposition Using Mycoflora for Sustainable Environment
}

\author{
${ }^{\text {R}}$ Raj Singh and ${ }^{1}$ Sushil Kumar Upadhyay \\ Department of Biotechnology, Maharishi Markandeshwar (Deemed to be University), \\ Mullana- Ambala, Haryana, India. \\ Corresponding Author: sushil.upadhyay@mmumullana.org
}

\section{Manuscript Details}

Manuscript Submitted : 03/05/2019

Manuscript Revised : :06/05/2019

Manuscript Accepted : 12/05/2019

Manuscript Published : 15/05/2019

\section{Available On}

https://plantaescientia.website/ojs

\section{Cite This Article As}

Singh R. and S K Upadhyay (2019). A study on the plant litter decomposition using mycoflora for sustainable development., Pla. Sci. 2019; Vol. 02 Iss. 01:11-14.

DOI: https://doi.org/10.32439/ps.v2il.11-14

\section{Copyright}

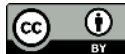

(c) The Author (s). 2019. Open Access This article is distributed under the terms of the Creative Commons Attribution 4.0 International License http://creativecommons.org/licenses/by/4.0/

\section{$\underline{\text { Indexed In }}$}

Crossref, Index Copernicus International (ICI), Directory of Research Journal Indexing (DRJI), Scientific Indexing Services (SIS), CiteFactor,

\begin{abstract}
Most of the agricultural, forest and field crop litters are consisting lignocelluloses, cellulose, hemicellulose and lignin. Among these cellulose is most predominant constituent followed by hemicellulose and lignin. The lignin together with the hemicellulose, encrust the cellulose chains forming a barrier which prevents wetting and access of cellulose-degrading enzymes therefore, the decomposition of litters can be achieved by breaking this association at first. The biodegradation of lignin of field crop litters representing a key step for carbon recycling inland ecosystem, as well as for industrial utilization of plant biomass, humification of dead organic matter by the application of certain bacterial and fungal species. The present study revealed the process of decomposition of plant litters. The fungal species colonized different types of plant litters on the basis of enzymatic activities and resource specificity. The mixtures of microorganisms could degrade lignocellulosic materials of wheat stubbles more efficiently than any individual species; Aspergillus niger, Aspergillus flavus, Aspergillus terreus, Fusarium equiseti, Trichoderma lignorum and Stachybotrys atra. A mixture of fungi and Streptomyces caused $48.0 \%$ decomposition while decomposition by an individual species viz. Aspergillus flavus was $36.90 \%$ only. It was found that, fungi have better abilities to decompose wheat straw than bacteria and actinomycetes. The mineralisation of plant residues could accelerate the rate of decomposition.
\end{abstract}

Keywords: Plant litters, Resource specificity, Decomposition Trichoderma lignorum; Stachybotrys atra 


\section{INTRODUCTION}

Studies on the role of individual fungal species in the process of decomposition can be traced back to Koning (1904) who inoculated Trichoderma koningi and Cephalosporium koningi upon sterile leaves covered with a little water. At the end of several weeks, the leaves disappeared, and water contained $\mathrm{NH}_{3}$. Lindeberg (1944) reported that Mycena galopus could decompose $37.0 \%$ of the dry matter of Beech, Fagus sp. (Angiosperm: Fagaceae) litter in 6 months at $25^{\circ} \mathrm{C}$. Hering (1967) found that Mycena galopus and another fungus, Collybia personata caused the greatest decomposition of oak leaf litter. Frankland (1969) found Mycena galopus to cause greatest loss in the bracken petioles when compared with many of the fungi imperfect. Initially, in the first 3 months, it caused small change in weight which was attributed to its slow spread over the litter. Afterwards, the fungus became considerably active, maintained its activity during the following 90 days period of study, while other fungi declined their activity. Trichoderma viride decomposed cellulose only when the substrate was treated with calcium nitrate. Singh et al. (2016c) also find out the decomposer microorganisms on the different substrates.

\section{PLANT LITTER DECOMPOSERS}

Dawson (1949) studied the capacity of a number of individual fungal strains from among soil fungi to decompose wheat straw in vitro. However, he did not refer to any species but only numbered the isolates of same genus like Aspergillus no. 1,2 , etc. Some of the strains were found to be successful decomposers. It was found that different fungi vary greatly in their ability to attack straw. Rhizopus and Penicillium were relatively inactive while Fusarium and Chatomium were vigorously active. Wani and Shinde (1977) also attempted to screen wheat straw decomposing microorganisms in vitro. They studied only a few strains of microorganisms, mostly bacteria. Kapoor et al. (1978) studied the extent of degradation of cellulose and lignin in wheat straw as a result of inoculation with Botryotrichum sp., Masoniella sp., Paecilomyces fusisporus, Sclerotium sp. and Trichurus spiralis. Botryotrichum sp. and Sclerotium sp. were found to degrade lignin up to $22 \%$ within 15 days. Gaur (1979) found that two species of Penicillium and Aspergillus could decompose 46\% and $36 \%$ of the straw respectively. Singh and Charaya (2003) investigate the fungal colonization of decomposing aboveground residues of wheat crop and 46 fungi were isolated. Chatterjee and Nandi (1980) observed that the mixtures of microorganisms could degrade lignin and holocellulose of wheat stubbles more efficiently than any individual species. A mixture of fungi and Streptomyces caused 48.0\% decomposition while decomposition by an individual species viz. Aspergillus flavus was $36.90 \%$ only. Chaturvedi (1984) found fungi to have better abilities to decompose wheat straw than bacteria and actinomycetes. The order of ability of individual test fungi to decompose the sterilized litter was Cunninghamella echinulata, Aspergillus flavus, A. niger, Trichoderma viride, Fusarium oxysporum, Penicillium chrysogenum, Cladosporium cladosporioides, Rhizopus nigricans, Myrothecium roridum, Neocosmospora vasinfecta. T viride, P. chrysogenum and M. roridum were more active on unsterilized litter. Charaya (1985) tested the capability of a number of fungi to decompose wheat and paddy crop residues in vitro. Emericella nidulans was the most successful decomposer of wheat straw followed by Myrothecium verrucaria, Alternaria alternata, Penicillium oxalicum, Fusarium semitectum, Cladosporium cladosporioides and Stachybotrys atra. Magan et al. (1989) failed to detect any marked improvement in decomposition of wheat straw in soil as a result of inoculation with Gliocladium roseum, Trichoderma harzianum or Penicillium hordei. Omar (1994) investigated the decomposition and mineralisation of wheat straw inoculated with cellulolytic fungi in sand culture. Aspergillus fumigatus and Stachybotrys chartarum showed a great potential to degrade wheat straw. Singh et al. (2017a,b,c; 2018a,b) studied the cellulolytic, hemicellulolytic, pectolytic and lignolytic potential of fungi in the decomposition of wheat straw.

Rege (1927) studied the decomposition of rice straw by Coprinus sp., Aspergillus fumigatus and Acremonium velutina, individually as well as in combinations. The maximum decomposition was achieved in combination of all the three. All the three fungi could decompose rice straw to different degrees. Prakash and Saksena (1952) studied the capacity of 22 fungi to decompose paddy straw. Maximum loss in weight of the straw was recorded in the case of Penicillium luteum but maximum total carbon decomposition was recorded in the case of Chatomium sp. $\mathrm{pH}$ of straw or the oxidase activity of fungi were not found to have a correlation with decomposition. Mukhopadhyay and Nandi (1979) found Curvularia sp. to be most efficient decomposer of rice stumps while Chatterjee and Nandi (1981) found Geotrichum candidum and Oospora lactis to be the best degraders of rice stumps. Slight decomposition (6-8\%) of Sphagnum spp. incubated with Trichoderma lignorum or Penicillium spinulosum was recorded by Minchevich (1969). In similar cultures, Collybia dryophila can destroy about $30 \%$ of the dry matter in less than four months, but this is considerably less than in the Bryales (53-56\%) and angiosperm litter (46-69\%) tested under same conditions (Mikola, 1956).

Hering (1967) found that the difference in the rates of decomposition of autoclaved and irradiated litter (when inoculated with Trichoderma viride) were not large though the rate was only slightly more in the former which, in his 
opinion, was due to the breakage of cellulose fibres and hydrolytic release of nutrients. Singh et al. (2015a; 2016a) stated that different biochemical constituent viz lignin, cellulose, hemicellulose and pectin degraded at different rate inoculated by Trichoderma lignorum.

Ivarson (1974) studied the survival and decomposing ability of four dominant fungi isolated from coniferous-deciduous leaves over a period of 45 months and found that Rhizoctonia sp., whether alone or in association with other fungi, had low survival ability and would seem to be of little importance in the decomposition of the litter. Mucor spinescens alone, at $10^{\circ} \mathrm{C}$ and room temperature, survived and brought about some decomposition. In mixed culture, it aided in the process of decomposition. Singh et al. (2016b, d) established the role of microorganism and microfauna in plant litter decomposition.

Aneja (1978) found Chaetomium erectum and Aspergillus flavus to possess maximum ability to decompose Desmostachya and Chenopodium litter respectively. Dube et al. (1980) observed that Cladosporium herbarum, Aspergillus niger and Aspergillus flavus possessed very good capacity to decompose mango leaves. The decomposition was rapid in the first 11 days, slowing down during the next 10 days. Singh et al. $(2015 b, C)$ investigated the lignocellulolytic potential of Aspergillus niger, Aspergillus flavus, Aspergillus terreus, Fusarium equiseti, Trichoderma lignorum and Stachybotrys atra.

\section{FACTORS INFLUENCING THE LITTER DECOMPOSITION}

Kang et al. (1995) found that the addition of ammonium sulfate $\left[\left(\mathrm{NH}_{4}\right)_{2} \mathrm{SO}_{4}\right]$ promoted the composting of paddy straw inoculated with cellulolytic microorganisms. Nandi et al. (1999) found that Phanerochaete chrysosporium, in combination with Trichurus spiralis, caused maximum decomposition of sawdust. Cox et al. (2001) have established the importance of understanding the effects of specific fungi in the process of litter decomposition as compared to diverse communities. Singh et al. $(2016 \mathrm{~b}, \mathrm{~d})$ find out the host-specific decomposers of plant litters.

Koutev et al. (2001) studied the rate of mineralisation of nitrogen from straw using "BIOSMOSEO" (a special microbiological strain adapted in decomposition of plant residues). They found that the agent increased the rate of mineralisation of nitrogen from straw for the first 14 days of incubation. Singh and Charaya (2010); Singh et al. (2015d) find out the effect of Nitrogen and Phosphorous on the decomposition of post-harvested wheat crop residues.

\section{ACKNOWLEDGEMENT}

Authors are very thankful to the Head, Department of Biotechnology, M.M.E.C., Maharishi Markandeshwar (Deemed to be University), Mullana, Ambala for constant support during compilation of findings

\section{REFERENCES}

Aneja, K. R. (1978). Taxonomical and ecological studies on litter and soil fungi from grasslands of Kurukshetra. Ph.D. Thesis, Kurukshetra University, Kurukshetra, India. https://doi.org/10.29252/arakmu.10.3.19

Charaya, M. U. (1985). Taxonomical, ecological and physiological studies on the mycoflora decomposing wheat and paddy crop residues. Ph.D. Thesis. Chaudhary Charan Singh University, Meerut, India.

Chatterjee, S. K. and Nandi, B. (1981). Role of some mesophilic soil organisms in rice stubble degradation. International Biodeterol. Bulletin 17, 133-139.

Chatterjee, S.K. and Nandi, B. (1980). Biodegradation of wheat stubbles by some soil microorganisms. Proceedings of RRAI Symposium Punjab Agriculture University, Ludhiana pp275-280.

Chaturvedi, A. P. (1984). Effect of some dominant litter microflora on rate of root decomposition. Proceedings of the $7^{\text {th }}$ All Indian Botanical Conference 15p.

Cox, P., Wilkinson, S. P. and Anderson, J. M. (2001). Effects of fungal inocula on the decomposition of lignin and structural polysaccharides in Pinus sylvestris litter. Biology and Fertility of Soil 33(3), 246-25l. https://doi.org/10.1007/s003740000315

Dawson, R. C. (1949). Soil Science 67, 467-479.

Dube, V. P., Charaya, M. and Modi P. (1980). Ecological and in vitro studies on the soil mycoflora of mango orchards. Proceedings of the Indian Academy of Sciences (Section A) 89(2), 151-160

Frankland, J. C. (1969). Fungal succession of bracken petioles. Journal of Ecology 57, 25-36.

Gaur, A. C. (1979). Organic recycling prospects in Indian agriculture. Fertilizer News 24, 49-61

Hering, T. F. (1967). Fungal decomposition of oak leaf litter. Transactions of the British Mycological Society 50, 267-273. https://doi.org/10.1016/s0007$\underline{1536(67) 80037-8}$

Ivarson, K. C. (1974). Comparative survival and decomposition ability of four fungi isolated from leaf litter at low temperature. Canadian Journal of Soil Science 54, 245-253. https://doi.org/10.4141/cjss74-033

Kang, H. W., Nam, M. H., Rhee, I. K., Ko, J. Y., Park, K. B. and Kim, J. H. (1995). Isolation and Characteristics of cellulolytic microorganisms for composting rice straw. 2. Effect of Cellulolytic microorganisms isolation on rice straw composting. RDA Journal of Agricultural Science- Soil and Fertilizer 37, 275-281.

Kapoor, K. K., Jain, M. K., Mishra, M. M. and Singh, C. P. (1978). Cellulolytic activity, degradation of cellulose and lignin and humus formation by cellulolytic fungi. Annals of Microbiology (Inst. Pasteur) 129B, $613-620$.

Koning, C. J. (1904). Arch Neerland Sci. Exact et Nat. S-2 (quoted by Rege, 1927).

Koutev, V., Guiraud, G. and Marol, C. (2001). Effect of decomposing agent on the mineralization of nitrogen from labelled straw. Pochvoznanie, Agrokhimiya. Ekologiya 36, 146-148. 
Lindeberg, G. (1944). Uber die physiologic ligninabbauender Bodenhymenomyzeten. Symb Bot Upsal 8, 1-183.

Magan, N., Hand, P., Kirwood, I. A. and Lynch, J. M. (1989). Establishment of microbial inocula on decomposing wheat straw in soil of different water contents. Soil Biology and Biochemistry 21(1), 15-22. https://doi.org/10.1016/0038-0717(89)90004-7

Mikola, P. (1956). Metsatiet Tutkimuslait Julk 48, 1-22.

Minchevich, G. P. (1969). Nauchn. Tr. Leningr. Lesotekh. Akad. 128, 63-65.

Mukhopadhyay, D. and Nandi, B. (1979). Biodegradation of rice stumps by soil mycoflora. Plant and soil 53, 215-218.

https://doi.org/10.1007/bf02181892

Nandi, N., Rahman, F. H., Sinha, N. B. and Hajra, J. N. (1999). Effect of cellulolytic and lignoclastic fungal cultures on the decomposition of saw dust. Journal of Interacademica 3, 37-40.

Omar, S. A. (1994). Degradation and mineralization of wheat straw by some cellulolytic fungi in pure cultures. Microbiological Research 149(2), 157-161 https://oi.org/10.1016/s0944-5013(11)80112-6

Prakash, R. and Saksena, R. K. (1952). Decomposition of paddy and bajra (Pennisetum typhoideum) straws by fungi commonly found in Allahabad soils Proceedings of Indian Academy of Science 36(B), 119-128.

Rege, R. D. (1927). Biochemical decomposition of cellulosic materials, with special reference to the action of fungi. Annals of Applied Biology 14, 1-44 https://doi.org/10.1111/j.1744-7348.1927.tb07004.x

Singh R. and Charaya M. U. (2003). Fungal colonization of decomposing above-ground residues of wheat crop. Bulletin of Pure and Applied Sciences 22B(1), 55-59.

Singh R. and Charaya, M. U. (2010). Effect of Urea and Single Super Phosphate on in vitro decomposition of wheat crop residues by Trichoderma Lignorum. Bulletin of Pure and Applied Sciences 29B(2), 63-73.

Singh R. Upadhyay, S. K, Rani, A., Kumar, P., Singh, M., Kumar, P., and Kumar, V. (2018a). A review on enzymes and substrate colonization by microflora Bioscience Research Bulletin 34(1), 27-32. https://doi.org/10.5958/2320-3161.2018.00003.2

Singh R., Charaya M. U., Shukla L., Shukla G., Kumar A., and Rani, A. (2015b). Lignocellulolytic potentials of Aspergillus terreus for management of wheat crop residues. Journal of Academia and Industrial Research 3(9), 453 455. https://doi.org/10.5958/2322-0996.2015.00010.1

Singh R., Shukla G., Kumar A., and Rani A. (2015c). "Decomposition of wheat residues by fungi. Journal of Academia and Industrial Research 4(1) 37-39.

Singh, R., Charaya, M. U., Kumar, A., Shukla, G., Rani, A. and Kumar, P. (2015d). Rate of decomposition of plant litter and factor affecting it. International Journal of Biological Sciences, Biotech Today 5(1), 5l-55.

Singh, R., Rani A., Kumar, A and Girdharwal, V. (2015a). Biochemical changes during in vitro decomposition of wheat residue of Trichoderma lignorum (Tode) Harz. International Journal of Advanced Information Science and Technology 4(8), 29-30. https://doi.org/10.5958/23203196.2017.00004.0

Singh, R., Rani, A. Kumar, P., Kumar, A., Shukla, G. and Mohd., J. (2016d). Role of microorganism and microfauna in plant litter decomposition. International Journal of Engineering Sciences and Research Technology 5(5), 592-597. https://doi.org/10.5958/2320-3161.2016.00006.7

Singh, R., Rani, A., Kumar, A., Kumar, P., Shukla, G. and Mohd., J. (2016b). Host-specific plant litter decomposers in the environment. Global Journal for Research Analysis 5(3), 50-52.

Singh, R., Rani, A., Kumar, P, Shukla, G. and Kumar, A. (2016c). The decomposer microorganisms in the environment and their succession of substrates.
International Journal of Engineering Sciences and Research Technology, 5(7), 1166-1171.

Singh, R., Rani, A., Kumar, P, Shukla, G. and Kumar, A. (2017a) Cellulolytic activity in microorganisms. Bulletin of Pure and Applied Sciences 36B(1), 28-37.

Singh, R., Rani, A., Kumar, P, Shukla, G. and Kumar, A. (2017b). Hemicellulolytic activity in the crop residues. International Journal of Pharmaceutical Research 9(3), 18-20.

Singh, R., Rani, A., Kumar, P. and Prasad, N. (2017c). Pectolytic activity in microorganisms and their enzymes. International Journal of Contemporary Research in Engineering and Technology 7(2), 33-34.

Singh, R., Rani, A., Kumar, P., Sharma, A., Shukla, G. and Kumar, A. (2016a). Biochemical changes during decomposition. Bioscience Research Bulletin 32(1), 45-50

Singh, R., Upadhyay, S. K., Rani, A., Kumar, P., Kumar, A., and Singh, C. (2018b). Lignin biodegradation in nature and significance. Vegetos 31(4), 3944. https://doi.org/10.5958/2229-4473.2018.00091.5

Wani, S. P. and Shinde, P.A. (1977). Studies on biological decomposition of wheat straw I. Screening of wheat straw decomposing microorganisms in vitro. Plant and Soil 47, 13-16. https://doi.org/10.1007/bf00010363

(C) 2019| Published by Plantae Scientia 